\title{
Infrastructure and Career Opportunities in Addiction Science: The Emergence of an Interdisciplinary Field
}

\author{
Thomas F. Babor, Dominique Morisano, \\ Jonathan Noel, Katherine Robaina, \\ Judit H. Ward and Andrea L. Mitchell
}

\begin{abstract}
Introduction
During the latter part of the 20th century, there was rapid growth in the number of people employed in the societal management of social and medical problems associated with the use of alcohol, tobacco, and illicit drugs (Edwards \& Babor, 2012). At the same time, similar growth occurred in the number of institutions and individuals engaged in addiction science. The current worldwide infrastructure of addiction science includes numerous research funding sources, more than 90 specialized scholarly journals, scores of professional societies, over 200 research centers, more than 80 specialty training programs, and thousands of scientists.

The purpose of this chapter is to describe the global infrastructure supporting addiction science and the career opportunities available to addiction scientists. The current global infrastructure is evaluated from two perspectives: (a) its ability to produce basic knowledge about the causes of addiction and the mechanisms by which psychoactive substances affect health and well-being and (b) its ability to address substance-related problems throughout the world at both the individual and the population levels. The first perspective speaks
\end{abstract}

\section{How to cite this book chapter:}

Babor, T F, Morisano, D, Noel, J, Robaina, K, Ward, J H and Mitchell, A L. 2017. Infrastructure and Career Opportunities in Addiction Science: The Emergence of an Interdisciplinary Field. In: Babor, T F, Stenius, K, Pates, R, Miovský, M, O’Reilly, J and Candon, P. (eds.) Publishing Addiction Science: A Guide for the Perplexed, Pp. 9-34. London: Ubiquity Press. DOI: https://doi.org/10.5334/bbd.b. License: CC-BY 4.0. 
to the mission of science to produce fundamental knowledge. The second is a public health mission that is often used to justify societal investments in clinical and translational research.

This chapter begins with a discussion of the meaning of addiction science as an interdisciplinary field of study. We then consider six areas of infrastructure development: (a) specialty journals; (b) research centers; (c) professional societies; (d) specialized libraries and documentation centers; (e) training and education programs; and (f) funding agencies. We close with a discussion of the career opportunities and future directions of addiction science.

\section{What is Addiction Science?}

The multidisciplinary area of "addiction studies" (variously called addictology, narcology, alcohology) is generally devoted to the understanding, management, and prevention of health and social problems connected with the use of psychoactive substances. Within this area of addiction studies, addiction science represents a more specialized subarea of research activity applying the scientific method to the study of addiction. Over the past 150 years, addiction science has developed its own terminology, concepts, theories, methods, workforce, and infrastructure. Addiction science merges biomedical, psychological, and social perspectives within a transdisciplinary, issue-driven research framework. The goal is sometimes stated as an attempt to advance physical, mental, and population health by contributing to prevention, treatment, and harm reduction.

The field of addiction science, like other interdisciplinary areas of research, often requires expertise and collaborations across traditional disciplinary boundaries as well as transdisciplinary research efforts (Choi \& Pak, 2006) that involve scientists trained in the basic sciences, medicine, and public health, as well as the social, biological, and behavioral sciences. It also encourages integration of nonacademic participants, such as policymakers, service providers, public interest groups, and persons in recovery from substance use disorders. The basic underlying framework, or infrastructure, of current addiction science consists of research centers, scholarly journals, professional societies, education programs, specialized services, specialized libraries, funding agencies, and the people to populate these institutions and services.

Box 2.1 provides an abbreviated chronology of major events in the development of addiction science in North America, Europe, and other parts of the world.

The first wave of activity consisted of establishing organizational and communication structures such as the American Association for the Study and Cure of Inebriety in 1870, and its British counterpart, the Society for the Study and Cure of Inebriety in 1884. The emergence of addiction science was driven primarily by societal concerns about the problems of alcohol and, later, about cocaine and opiates. Addiction science initially flowered and then nearly expired in concert 


\section{- First Wave: Organizational and Communication Structures}

- 1870 - American Association for the Study and Cure of Inebriety

-1884 -Society for the Study and Cure of Inebriety (United Kingdom)

-1907 - International Bureau Against Alcoholism

\section{- Second Wave: Institutional Support for Research}

-Early 1940s - Yale Center of Alcohol Studies, New Haven, Connecticut, United States

- 1949 - Addiction Research Foundation, Toronto, Canada

- 1950 - Finnish Foundation for Alcohol Studies, Helsinki, Finland

- 1960 - National Institute for Alcohol Research, Oslo, Norway

- 1967 - Addiction Research Unit, London, United Kingdom

- 1971 - U.S. National Institute on Alcohol Abuse and Alcoholism

-1973 - U.S. National Institute on Drug Abuse

\section{- Third Wave: The Modern Era}

- Addiction research centers

- Addiction specialty journals

-Addiction-focused professional societies

- Addiction-focused education and training programs

-Addiction-focused libraries

Box 2.1: Major milestones in the history of addiction science.

with the rise and fall of the temperance movement in America and Europe. During a 40-year period (1875-1915), an international cadre of addiction specialists emerged from various areas of medicine and science to advance knowledge about addiction problems. This was done by means of professional societies, international meetings, scientific journals, scholarly books, and expert committee reports (Babor, 1993a,b; 2000; Billings et al., 1905; Bühringer \& Watzl, 2003; Sournia, 1996). Although the research produced by these organizations was unsophisticated by current standards, there were some notable advances in toxicology, clinical diagnosis, epidemiology, and policy research during this time (Babor, 1993a, 2000; Billings et al., 1905; Sournia, 1996), especially in the United Kingdom, the United States, France, Germany, and Sweden. The demise of addiction studies followed the imposition of prohibition legislation in the United States, Scandinavia, the United Kingdom, and many other countries in the aftermath of the First World War. It was not until the 1940s that addiction research regained a sense of identity and purpose and not until the 1970s when it gained enough scientific respectability to be considered a legitimate part of society's public health response to alcohol and other drug problems. 
The second wave of addiction science is characterized by the growth of institutional support for research, beginning with the establishment of the Yale Center of Alcohol Studies in New Haven, Connecticut, in the United States in the early 1940s; the Addiction Research Foundation, Toronto, Canada, in 1949; and similar organizations in Finland, Germany, Norway, and other countries. With the creation of government funding agencies at the federal level in the United States in the early 1970s, the stage was set for the modern era.

As part of the developing biomedical establishment in the United States, addiction science experienced phenomenal growth, which was paralleled by similar developments in Europe. That growth-the third wave-can be characterized by at least four megatrends (Babor, 1993b): (a) the rapid expansion of scientific publishing of addiction research, (b) the development of addiction research centers and related organizational structures, (c) international collaboration in research, and (d) the development of significant scientific breakthroughs in addiction science and medicine. We now consider these trends in the context of the seven types of infrastructure that have emerged in the modern era described above.

\section{Addiction Specialty Journals}

One indication that addiction science has emerged as a separate discipline is the appearance of specialty academic journals that serve as a medium of communication among clinicians and scientists. The first journals specifically publishing addiction science were the (quarterly) Journal of Inebriety (1876-1914), the British Journal of Inebriety (1884-present; now Addiction) and the International Monthly Journal for the Fight against Drinking Practices (1890-present with two World War interuptions; now SUCHT). After a relative lapse of interest in addiction science, the Quarterly Journal of Studies on Alcohol (now the Journal of Studies on Alcohol and Drugs) was established in 1940 and revived scientific interest in alcoholism, a development that began the modern era of addiction research.

Figure 2.1 traces the cumulative growth of addiction specialty journals since 1884. The journals are characterized in terms of their language of publication (English and non-English), but there are other important distinctions that are discussed in more detail in Chapter 3. The dominance of English as the international language of science has facilitated communication far beyond national boundaries. With the development of online publishing and the "open access" trend to make scientific research freely available to the scientific community and the general public, there has been a proliferation of online open-access English-language journals that have transformed the way that scientific information is published and distributed. However, as discussed in Chapter 3, many of the new online open access journals that have been established in the last decade are produced by "predatory publishers", organizations that engage in 


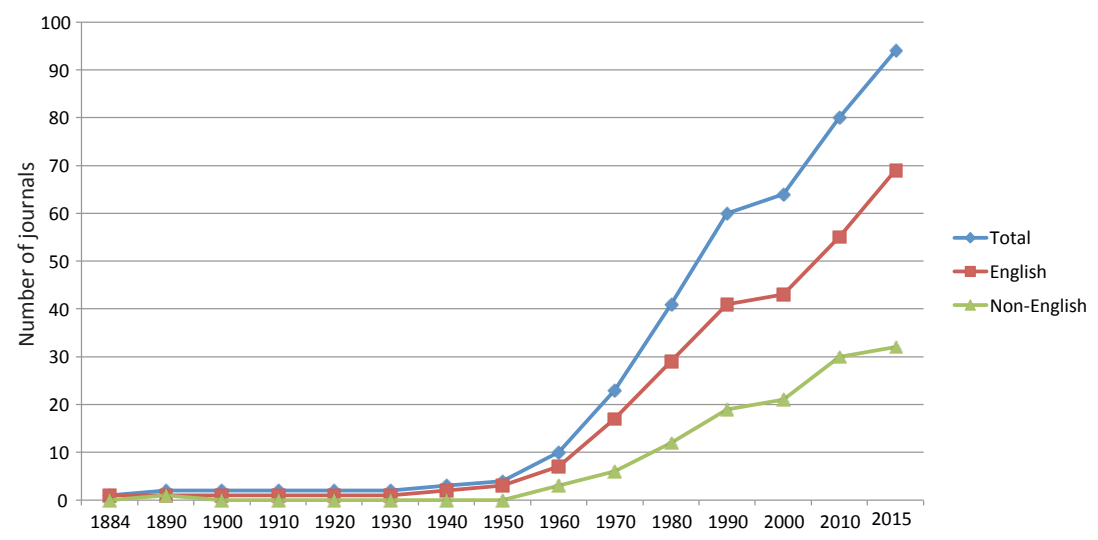

Fig. 2.1: Growth of addiction specialty journals.

questionable practices with regard to journal management, marketing activities, peer review, and page fees (Beall, 2012).

Addiction specialty journals provide a communication forum for scientists and clinicians. They deliver valuable information to practitioners, scientists, and the general public. They set the agenda for a field of study and maintain ethical and quality standards. Another function is to archive the historical record for an area, allowing permanent access to articles for future use by scientists, clinicians, administrators, policymakers, and historians. Finally, by means of the peer-review process, journals certify the authenticity and originality of an author's work (LaFollette, 1992). For these reasons, scientific journals are the institutional memory of a field.

In addition to the growth in specialty journals, addiction science is also published by discipline-oriented journals dealing with medicine, pharmacology, biochemistry, neurobiology, psychology, sociology, and epidemiology. When the addiction articles of these journals are combined with the publications in addiction specialty journals, it becomes possible to estimate trends in the volume of research in addiction science by means of historical records and bibliometric analyses. Between 1900 and 1950, for example, approximately 500 scientific articles were published per year on alcohol (Keller, 1966). Between 1950 and 1970, the number of publications doubled each decade. By the late 1980s, more than 3,000 scholarly publications on alcohol were appearing per year, and the trend has continued unabated until the present.

To estimate the current output of scientific publications, we used bibliometric procedures to extract journal publications in SCOPUS from 2000 through 2014 that dealt with addiction research (e.g., "alcohol use disorder" and "tobacco use disorder"). We then categorized the publications by area of focus across four areas of research: alcohol, tobacco, other drugs, and gambling. The SCOPUS 
database was selected for its inclusion of all MEDLINE journals. It should be noted that there is no single database that covers the entire output of scholarly publications in addiction science, after the major databases that previously collected, indexed, and abstracted addiction literature ceased operations over the past 15 years (ETOH in 2003, Rutgers Alcohol Studies Database in 2007, CORK in 2015). In the absence of a comprehensive database, it is difficult to estimate the number of articles published in the field, and it is not possible to give an accurate account of other addiction-related publications (e.g., books, reports). The estimates provided in this chapter should therefore be considered conservative and better suited to the identification of relative growth trends than to the estimation of the absolute number of publications.

The four searches yielded 233,970 results published since the year 2000 . We identified 212,891 unduplicated journal publications for all four areas of research, of which 79,585 were published between 2010 and 2014. Figures 2.2 and 2.3 show the trends in document production. The trend is generally positive for all areas until 2009 when a decline begins for tobacco and nicotine research, followed by lesser declines in 2013 for alcohol and other drugs. The decline in publications may be attributed to reductions in public research funding in the major research-producing countries as well as the global economic recession that began in 2008. This interpretation is supported by the absence of a decline in gambling research, which is mainly supported by the gambling industry or by tax revenues from state lotteries.

The geographical dispersion of the research publications was also examined. The country of origin of each article was determined from the address of the first or corresponding author. Publication contributions between 2010 and 2014 from the most research-prolific countries are shown in Table 2.1.

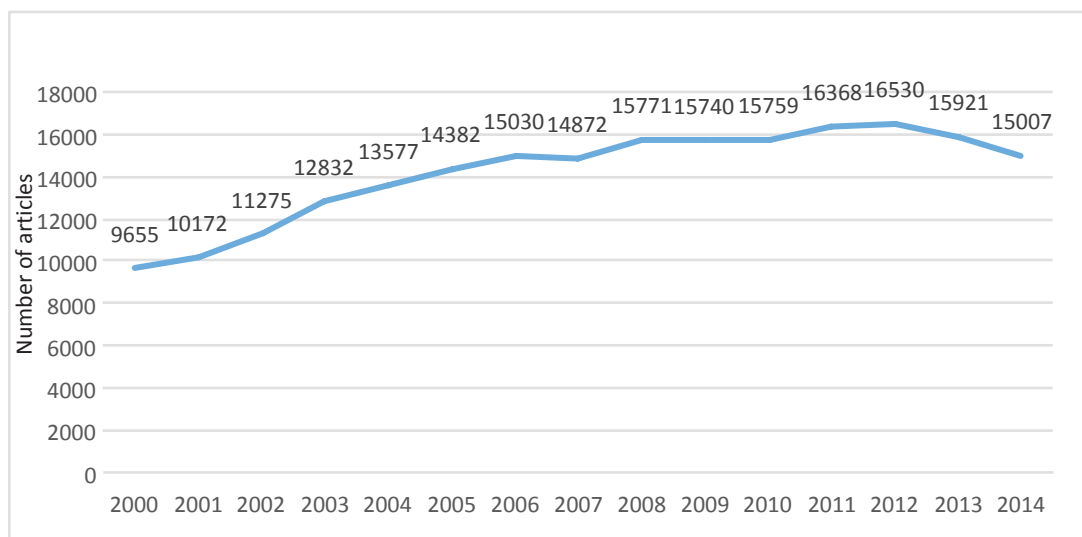

Fig. 2.2: Total number of addiction articles per year (2000-2014). 


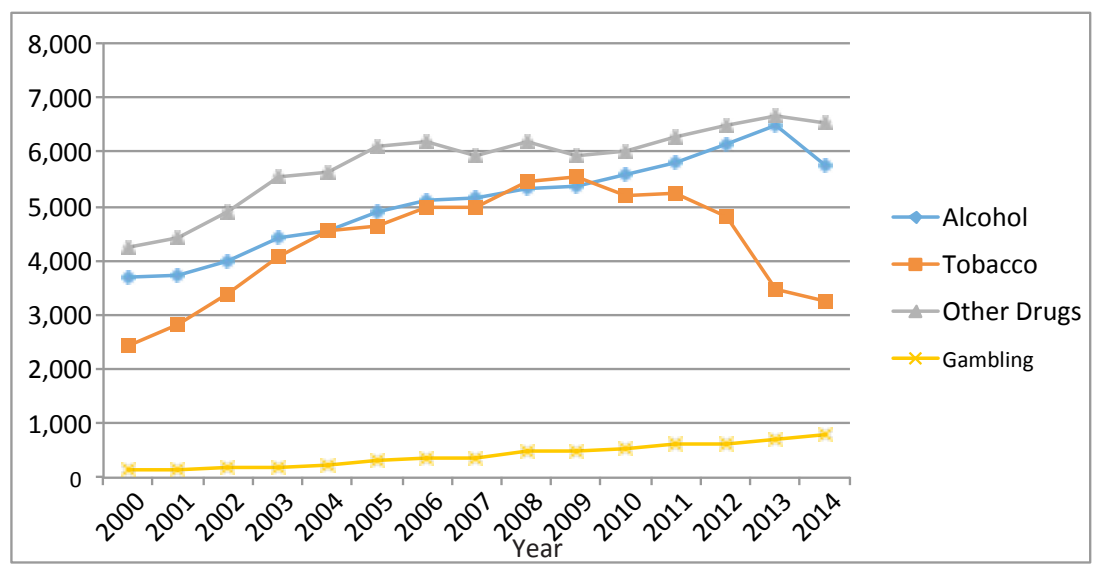

Fig. 2.3: Total number of addiction articles, by year and category (2000-2014).

\begin{tabular}{|l|c|c|c|c|c|}
\hline & Alcohol & Tobacco & $\begin{array}{c}\text { Other } \\
\text { drugs }\end{array}$ & Gambling & $\begin{array}{c}\text { Population- } \\
\text { adjusted } \\
\text { publication } \\
\text { rate }^{*}\end{array}$ \\
\hline United States & 12,479 & 9,115 & 14,201 & 1,067 & 10.45 \\
\hline United Kingdom & 2,421 & 2,236 & 2,601 & 382 & 10.99 \\
\hline Australia & 1,674 & 1,027 & 1,723 & 345 & 18.71 \\
\hline Germany & 1,430 & 879 & 1,280 & 206 & 4.35 \\
\hline Canada & 1,297 & 1,252 & 1,738 & 399 & 12.04 \\
\hline Italy & 996 & 780 & 1,233 & 159 & 4.90 \\
\hline France & 995 & 686 & 1,137 & 134 & 4.03 \\
\hline Spain & 978 & 661 & 1,322 & 108 & 5.99 \\
\hline The Netherlands & 902 & 707 & 817 & 105 & 13.83 \\
\hline Brazil & 838 & 303 & 786 & 64 & 0.90 \\
\hline China & 791 & 649 & 1,010 & 148 & 0.18 \\
\hline India & 755 & 614 & 553 & 18 & 0.14 \\
\hline Switzerland & 568 & 367 & 693 & 59 & 19.06 \\
\hline
\end{tabular}

Table 2.1: Publications by country and research category.

${ }^{*}$ Rates based on unduplicated totals from total population estimates from 2013; Source: World Bank (2013). 
When looking at the number of publications across all four categories combined (totals not shown), the top five producing countries are the United States, United Kingdom, Australia, Canada, and Germany. The United States accounts for approximately $42 \%$ of the total production, but on a population-adjusted basis several other countries (Australia, the United Kingdom, Canada, the Netherlands, and Switzerland) make even greater contributions. In the emerging economies of the world, China, India, and Brazil are beginning to produce significant amounts of the research published in the English-language literature as well. An important consideration regarding the geographic concentration of research in the United States and Europe is that the findings may not generalize to other parts of the world-especially nations in Africa, Asia, and Latin America-facing epidemics of alcohol abuse, nicotine dependence, other drug dependence, or pathological gambling. In general, these analyses indicate that the steady growth of addiction science during the latter part of the 20th century has continued unabated into the first part of the 21 st century.

\section{Addiction Research Centers}

Although addiction research in many countries is conducted by independent scientists whose primary affiliation is to an academic department in a university or by clinicians who work in treatment facilities, in recent years there has been an expansion of specialized centers whose primary purpose is to support alcohol, tobacco, and other drug research. As such, they provide a good indicator of growth trends in research infrastructure.

Centers provide dedicated facilities to groups of scientists and supporting staff so that long-term programmatic research can be carried out. Centers constitute an optimal environment for researchers, one that is relatively free of administrative, clinical, and teaching responsibilities. Not only are the positions dedicated exclusively to research, but the centers also provide the prospect of long-term support and career advancement. Training of junior investigators is another important function of research centers.

Building on earlier estimates of the annual growth in research centers (Babor, 1993b), we conducted an Internet search to identify the location and other characteristics of addiction research centers, including the dates they were established. We estimate that the number of research centers devoted to addiction research now number approximately 275 worldwide. The largest number of centers is located in the United States, the Nordic countries, the United Kingdom, Russia, Brazil, Canada, and Japan.

The growth of research centers is indicative of a more general trend in addiction science and clinical services. Over the last 45 years, the number of research centers has increased exponentially, from fewer than 20 before 1970 to more than 150 at the end of the century. By the year 2000, the multi-disciplinary research center had become the dominant setting for basic, clinical, and 


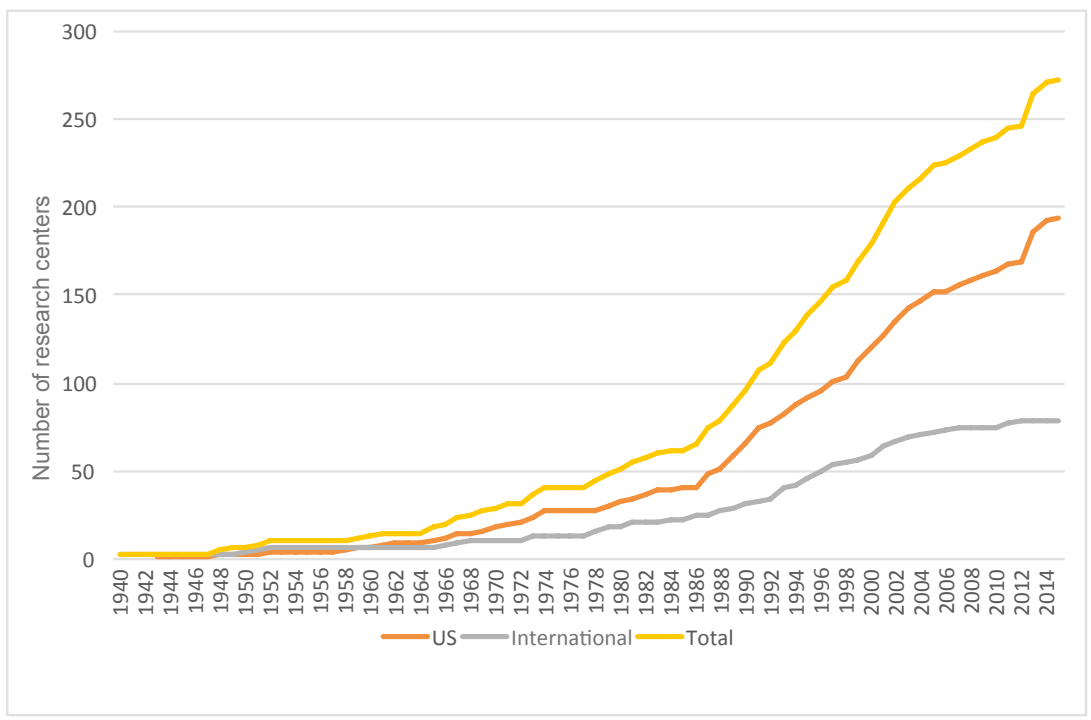

Fig. 2.4: Cumulative growth of addiction research centers (1940-2015).

psychosocial research on addictive substances. Figure 2.4 shows the exponential growth in addiction research centers in both the United States and globally over a 75 -year period. The scope of these centers varies, with $70.5 \%$ focusing on drugs and alcohol, $57.4 \%$ on alcohol alone, $36.0 \%$ on tobacco, and $2.9 \%$ on other addictions (e.g., problem gambling).

The type of addiction research varies across centers, with $55.6 \%$ conducting studies on addiction treatment, $54.2 \%$ on the psychosocial factors involved in addiction, $51.3 \%$ on policy or prevention programs, and $33.1 \%$ on the biological underpinnings of addiction. Approximately $8 \%$ of research centers are known to have more than 50 affiliated research scientists; $50 \%$ house fewer than 25 investigators; and $21 \%$ have fewer than 10.

As the number of centers has grown, collaborative networks have been formed to better leverage existing resources, conduct cross-national projects, train doctoral and postdoctoral candidates, write scientific publications, provide policy consultations, and increase the media coverage of addiction science. In Germany, the Federal Ministry of Education and Research implemented a long-term research funding program (1994-2008 with nearly 35 million euros) to enhance drug research and collaborations, disseminate findings, improve addiction-science information exchange across professionals, and advise the public and policymakers on addiction-related topics. The program supported 18 single projects and, from 2001 onwards, four consortia among 12 research centers (composed of MDs and psychologists) engaged in behavioral, clinical, neurobiological and genetic research (Mann, 2010). In that context, the first chair in addiction research was created in 1999 at the Central Institute of 
Mental Health Mannheim (University of Heidelberg) and the second in 2005 at the University of Dresden. In part because of the success of these networks, Germany is now investing substantially more in addiction research.

In the United States, the National Institute on Alcohol Abuse and Alcoholism (NIAAA) and the National Institute on Drug Abuse (NIDA) support research centers and research networks through several funding mechanisms. NIAAA supports 20 research centers through its National Alcohol Research Centers Program and also funds large-scale cooperative agreements among researchers collaborating on high-priority projects such as Project MATCH (Matching Alcoholism Treatments to Client Heterogeneity; Babor \& DelBoca, 2003), the multisite trial of Combined Pharmacotherapies and Behavioral Interventions for Alcohol Dependence (COMBINE; Anton et al., 2006), and the Collaborative Study on Genetics of Alcoholism (COGA) project (Agrawal \& Bierut, 2012). NIDA also supports a Clinical Trials Network (Wells et al., 2010) devoted to treatment research. These kinds of large-scale, cross-site collaborations facilitate rapid, standardized data-collection projects that would not be possible at a single small site, and they permit more generalizable conclusions and data applications.

Addiction research centers provide core facilities and laboratories, training opportunities for new scientists, and resources to sustain career investigators. In addition, research centers facilitate links between scientists, policymakers, and the general public. During the 75-year period depicted in Figure 2.4, there was parallel growth in governmental institutes and private funding agencies devoted to the sponsorship of addiction research. The combination of categorical support for addiction research and academic freedom to engage in addiction science as a career contributed substantially to the information and productivity explosion in the addiction field discussed in subsequent sections of this chapter (Babor, 1993a,b; Babor et al., 2008).

\section{Professional Societies}

In the addiction field, professional societies have been operating for almost 150 years, with the oldest continuing society being the Society for the Study of Addiction, established in 1884 in the United Kingdom. These societies include national and international organizations and sections of larger organizations that are devoted to addiction treatment, prevention, policy, and research. Membership comprises clinical, prevention, and research professionals, including psychologists, physicians, psychiatrists, social workers, addiction counselors, and other professional groups. Figure 2.5 documents the growth of professional societies, based on an earlier compilation of alcohol-related associations (NIAAA, 1985) and a review of Internet sources. The number of professional societies grew dramatically between 1970 and 2005, particularly in the United States. A more recent trend has been the growth of international organizations and confederations of societies. 


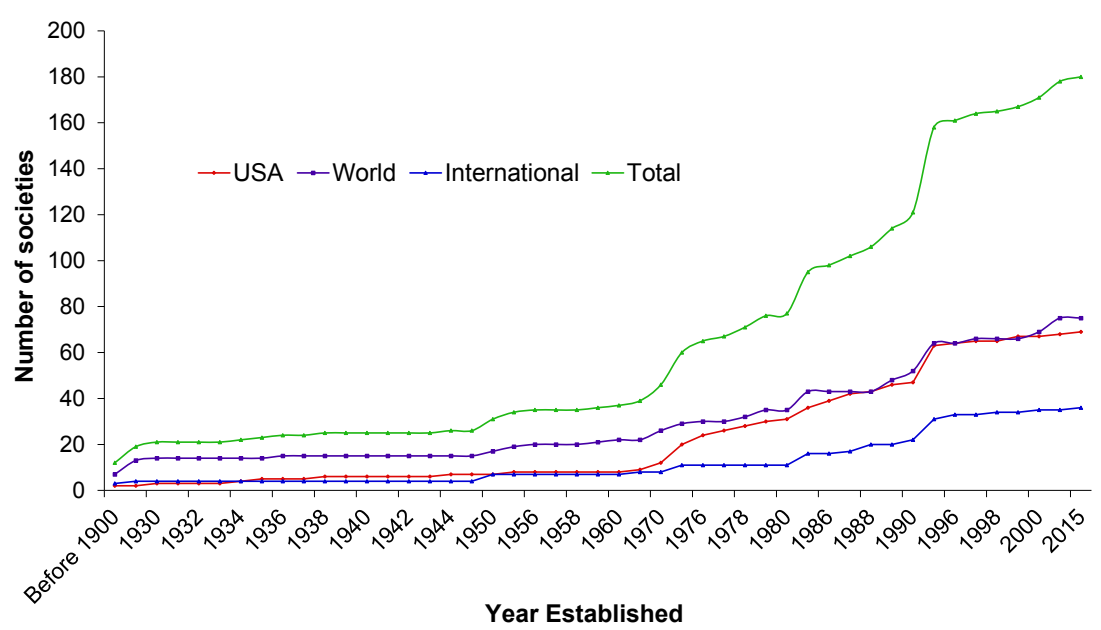

Fig. 2.5: Cumulative growth of professional societies.

A minority of these societies, perhaps no more than 40 in number, can be classified as addiction research organizations because their mission statements suggest primary involvement in issues related to research on alcohol, tobacco, other drugs, and behavioral addictions. Twelve countries have national-level research societies, and there are 14 international organizations. Only a few societies are located in developing countries. These organizations can be classified into three broad categories: multi-disciplinary, professional specialty, and research societies.

Multi-disciplinary societies are open to professionals of all disciplines who work in the addiction area, including treatment, prevention, research, policy, and education. The Brazilian Association for the Study of Alcohol and Other Drugs (ABEAD) is a good example of a multi-disciplinary national society, as is the British Society for the Study of Addiction. Professional specialty societies are typically special-interest groups organized within larger disciplinary societies, such as the Alcohol, Tobacco and Other Drugs section of the American Public Health Association. Several of these specialty societies are international in scope, such as the International Society of Addiction Journal Editors. Research societies provide a forum for new scientific developments and networking for potential investigative collaborations, usually within the context of an annual meeting. The Research Society on Alcoholism, College on Problems of Drug Dependence, and International Society for Biomedical Research on Alcoholism are examples of this type of organization.

Table 2.2 shows professional societies that sponsor scientific journals in terms of their year of foundation, membership numbers, and journal (adapted from Edwards \& Babor, 2008). These are among the largest societies devoted to research, representing more than 7,000 members, even taking into account multiple memberships by the same individuals across societies. 


\begin{tabular}{|c|c|c|c|}
\hline Name of organization & $\begin{array}{c}\text { Year } \\
\text { established }\end{array}$ & $\begin{array}{c}\text { Number of } \\
\text { members }\end{array}$ & Society journal(s) \\
\hline $\begin{array}{l}\text { Society for the Study of } \\
\text { Addiction (United Kingdom) }\end{array}$ & 1884 & 478 & $\begin{array}{l}\text { Addiction, Addiction } \\
\text { Biology }\end{array}$ \\
\hline $\begin{array}{l}\text { SOCIDROGALCOHOL: } \\
\text { Spanish Scientific Society } \\
\text { for the Study of Alcohol, } \\
\text { Alcoholism and other Drug } \\
\text { Dependencies }\end{array}$ & 1969 & 816 & Adicciones \\
\hline $\begin{array}{l}\text { Association for Medical } \\
\text { Education and Research in } \\
\text { Substance Abuse (United } \\
\text { States) }\end{array}$ & 1976 & 300 & Substance Abuse \\
\hline $\begin{array}{l}\text { Research Society on Alcoholism } \\
\text { (United States) }\end{array}$ & 1977 & 1,500 & $\begin{array}{l}\text { Alcoholism: Clinical } \\
\text { and Experimental } \\
\text { Research }\end{array}$ \\
\hline $\begin{array}{l}\text { ABEAD, Brazilian Association } \\
\text { for the Study of Alcohol and } \\
\text { Other Drugs }\end{array}$ & 1978 & 840 & $\begin{array}{l}\text { Society Bulletin } \\
\text { and the Brazilian } \\
\text { Journal on Chemical } \\
\text { Dependence } \\
\text { (Jornal Brasileiro } \\
\text { de Dependências } \\
\text { Químicas) }\end{array}$ \\
\hline $\begin{array}{l}\text { German Society for Addiction } \\
\text { Research and Addiction } \\
\text { Treatment }\end{array}$ & 1978 & 400 & SUCHT \\
\hline $\begin{array}{l}\text { Société Française d'Alcoologie } \\
\text { et Addictologie(French Society } \\
\text { of Alcoholism and Addiction) }\end{array}$ & 1978 & 807 & $\begin{array}{l}\text { Alcoologie et } \\
\text { Addictologie }\end{array}$ \\
\hline $\begin{array}{l}\text { Japanese Society of Alcohol- } \\
\text { Related Problems }\end{array}$ & 1979 & 543 & $\begin{array}{l}\text { Journal of the } \\
\text { Japanese Society } \\
\text { of Alcohol-Related } \\
\text { Problems }\end{array}$ \\
\hline $\begin{array}{l}\text { Australasian Professional } \\
\text { Society on Alcohol \& Other } \\
\text { Drugs }\end{array}$ & 1981 & 382 & $\begin{array}{l}\text { Drug and Alcohol } \\
\text { Review }\end{array}$ \\
\hline $\begin{array}{l}\text { Kettil Bruun Society for Social } \\
\text { and Epidemiological Research } \\
\text { on Alcohol }\end{array}$ & 1987 & 197 & $\begin{array}{l}\text { International Journal } \\
\text { of Alcohol and Drug } \\
\text { Research }\end{array}$ \\
\hline $\begin{array}{l}\text { Society for Research on } \\
\text { Nicotine and Tobacco }\end{array}$ & 1994 & 1,000 & $\begin{array}{l}\text { Nicotine \& Tobacco } \\
\text { Research }\end{array}$ \\
\hline
\end{tabular}

Table 2.2: Selected addiction societies according to year of foundation, membership, and journal sponsorship. 
Although the activities of professional societies are diverse, first and foremost they run meetings, ranging from large annual events to small topic-based workshops and thematic conferences. Networking-encouraging professionals to communicate and work with each other-is a major function, if not primary purpose, of these organizations. As noted in Table 2.2, many sponsor scientific journals. Some organizations influence national policy. ABEAD (Dias da Silva et al., 2002), for example, is close to the Brazilian government. Others stay clear of political involvement and focus on "science as science"; the German Society for Addiction Research and Addiction Treatment (Mann \& Batra, 2008) has supported the renaissance of the national addiction science base. Publications are another significant product of many societies, highlighting relevant research and achievements in the form of journals, yearbooks, bulletins, guidelines, and educational materials. Some societies provide continuing education to interested parties, with several offering professional certifications in addiction medicine or other relevant topics. Most societies share a common concern for enhancing the addiction field's status as an important area of research and clinical practice, with the aim of overcoming patient stigma and government neglect.

Some countries have just one major body dealing with alcohol and other drugs, whereas others have a plethora. Japan, for instance, has the Japanese Society of Alcohol-Related Problems, the Japanese Medical Society on Alcohol and Drug Studies, the National Society of Biomedical Research on Alcohol, the Society of Psychiatric Research on Alcohol, and a society focused on addiction behavior (Maruyama \& Higuchi, 2004).

Rather than being the products of government intention, many addiction societies were formed spontaneously by small groups of professionals who identified an emerging need and resolved to work together to address it. The British Society for the Study of Addiction, for example, was formed by an alliance of physicians in 1884 (Tober, 2004) to mobilize parliamentary support for the compulsory treatment of "inebriates." The impetus to the foundation in 1977 of the Research Society on Alcoholism was the expansion in research funding following the initiation of NIAAA (Israel \& Lieber, 2002). The Italian Association on Addiction Psychiatry (SIPDip) (Nizzoli \& Foschini, 2002) was established in 1989 to create a role for psychiatry in the face of political chaos and the neglect of addiction-related problems. Each of these societies was shaped by national trends in substance use, assumptions about the proper role of voluntary action, and the role of professional disciplines in the national response to addiction problems.

In the late 19th and early 20 th centuries, when the world temperance movement and specialized asylums for addiction treatment had reached a high level of maturity, large umbrella organizations or confederations were formed to facilitate communication among diverse addiction-related entities around the world. The first example of such a coalition of individuals and organizations was the The International Bureau Against Alcoholism, founded in 1907, which 
became, in 1964, the International Council on Alcohol and Alcoholism. More recently, confederations of research organizations have again begun to take shape in the addiction field with the creation of the European Federation of Addiction Societies (EUFAS) and the International Confederation of Addiction Research Associations (ICARA) (Stenius, 2012). The aim of ICARA is to provide a forum for the discussion of issues such as governance, organizational management, relationships with governments, advocacy for addiction science, and the promotion of treatment services. Another sign of the consolidation of infrastructure is the formation in 2001 of the International Society of Addiction Journal Editors (Edwards \& Babor, 2001).

According to Krimsky (2003), professional societies, along with a network of academic journals, define "acceptable scholarship and certifiable knowledge" (p. 107). Professional organizations, especially research societies, are a major resource for scientists working in biomedical and psychosocial research. They distribute news and scientific information to their members, publish journals and newsletters, engage in advocacy for research, coordinate scientific meetings, and at times facilitate collaborative research. These organizations, in turn, provide a means of networking and communication for their members. They confer prestige and often serve as advocates for professional issues such as research funding, the training of scientists, and evidence-based policy.

\section{Specialized Libraries and Databases}

Information services-including libraries, resource centers, and clearinghouses-are an integral part of any research program. A specialized library in the addiction field provides information resources, such as books and journals on addiction, as well as reports, pamphlets, and historical documents. Addiction libraries are usually managed by universities, government agencies, and nongovernmental organizations. With the growth of digital databases, addiction libraries have provided easy access to the international addiction literature.

Substance Abuse Librarians \& Information Specialists (SALIS) is a professional organization established in 1978 with assistance from NIDA and NIAAA. As an international association of individuals and organizations interested in the exchange of information on alcohol, tobacco, and other drugs (ATOD), SALIS provides a good example of the growth of specialization in addiction science. A major aim of SALIS is to promote the dissemination of accurate knowledge about the use and consequences of ATOD.

Figure 2.6 shows the cumulative growth and decline of specialized addiction libraries over the past 85 years in the United States and other parts of the world. The figure is based in part on an inventory compiled by SALIS (Mitchell, 1991) to document ATOD libraries, clearinghouses, and resource centers. From it, specialized libraries and collections that primarily serve an academic or research purpose were identified, although some documentation 
centers were also included. Libraries and other collections reporting fewer than 500 books were not included, nor were mental health libraries, those with no identifiable start date, resource centers, clearinghouses, or trade/ industry libraries, unless they served an academic purpose. The figure plots the cumulative number of functioning libraries by year established, subtracting any documented closures, based on a 2015 review that identified closures over the past 25 years.

The first specialized libraries were established in Europe (1907) and the United States (1940) during the early part of the 20th century. Starting in the 1940s, more ATOD libraries were added, a trend that accelerated in the 1960s. The global network of specialized libraries that SALIS now represents has followed a growth curve similar to other parts of the addiction science infrastructure, but there have also been signs of decline. The decline in the number of libraries after 1995 could be because of budget cuts that have affected libraries and databases in both North America and Europe, resulting in downsizing, service reduction, and closures. Another explanation is a change in information-seeking habits, with more professionals using the Internet to access information through their computers and smartphones (McTernan, 2016).

Regardless of the reason, specialized addiction libraries are declining in number, as are the number of specialized librarians. For example, in 2006, NIDA closed its library-which contained a collection dating from 1935. The U.S. Substance Abuse and Mental Health Services Administration (SAMHSA) also closed its prevention library and cut support to Regional Alcohol and Drug Awareness Resource (RADAR) centers, which were created to disseminate

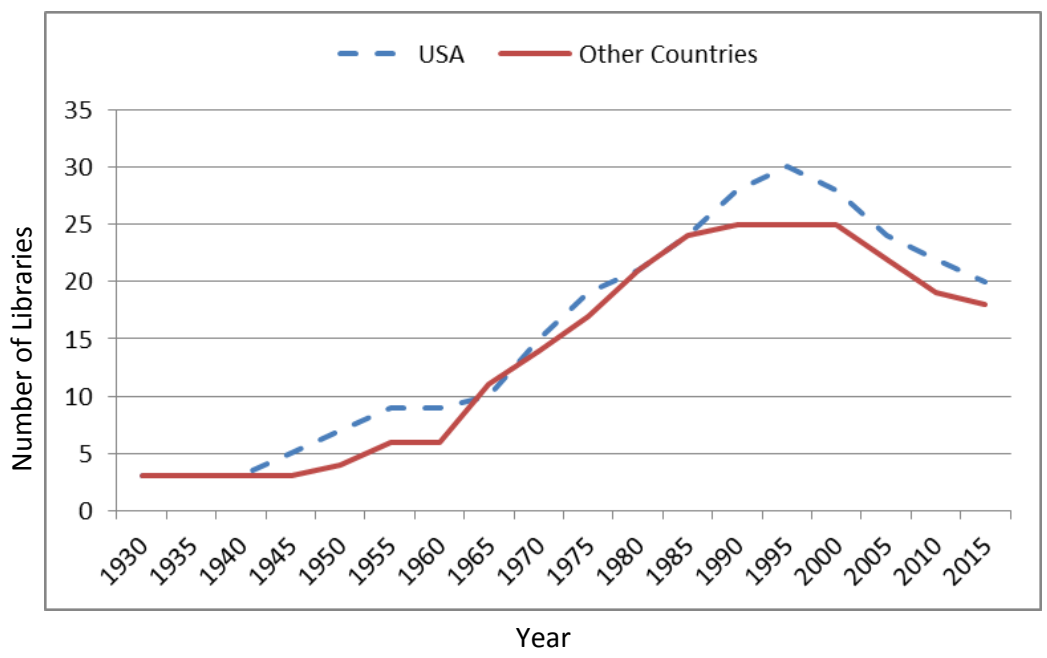

Fig. 2.6: Cumulative growth of specialized addiction libraries. 
government agency publications related to alcohol and other drugs. Europe joined the culling effort with library closures or downsizing at the Trimbos Institute (the Netherlands); Alcohol Concern, Drug Scope, and the Temperance Alliance (United Kingdom); Toxibase (France); and Gruppo Abele (Italy). Some of these organizations maintain online information portals, but collections have been packed up, databases and catalogues terminated, and staff positions eliminated. More than 25 libraries or databases have closed in the past decade (Mitchell et al., 2012). Not only have these closures resulted in a reduction in the ATOD information base, but they also have reduced the pool of librarians who have expertise and knowledge of valuable historical material. Print collections have been de-funded and neglected without ensuring archival preservation (Mitchell et al., 2012).

Budget reductions have been justified by the assumption that online access is "free," but the majority of scholarly literature cannot be accessed readily through search engines or websites because of copyright and the proprietary nature of information. Excluding PubMed, most research databases are available only through paid subscription. Furthermore, most do not provide fulltext articles without a fee.

In addition to specialized libraries, more than 100 companies and institutions currently offer abstracting and indexing services that provide digital access to abstracts and titles pertaining to the world literature on alcohol, other drugs, tobacco, and the behavioral addictions (e.g., problem gambling). There are approximately 20 main electronic databases that index the published literature by author, topic, and bibliographic reference and provide abstracts of articles for potential readers in search of particular types of information (see Chapter 3). Abstracting and indexing services provide detailed information about the content of scientific journal articles, including abstracts, which are invaluable for those without immediate access to the full text of the article. Some of the more specialized databases were established before the digital revolution in the 1990s, and, as their functions have been taken over by more generic databases, they have fallen into decline and neglect. For example, the Alcohol and Alcohol Problems Science Database, informally known as $\mathrm{ETOH}$, was a comprehensive online resource covering all aspects of alcohol abuse and alcoholism, including journal articles, books, conference papers and proceedings, reports and studies, dissertation abstracts, and chapters in edited works. Unfortunately, it ceased operations in 2003. Two other specialized databases, Project CORK and DrugScope, were closed in 2015, leaving the addiction field without a comprehensive digital repository of the world's addiction literature.

To the extent that library closures and downsizing of other information sources could be a bellwether of the future of addiction science, they are perhaps an indication that the exponential growth of the field has begun to slow or even decline. 


\section{Education and Training Programs in Addiction Studies}

Without career professionals to populate its infrastructure and develop its products, the addiction field would not exist. To fill the need for a growing professional workforce in treatment, prevention, and research, specialized education and training programs have been created throughout the world. Most of them focus on the training of clinicians, but several are devoted to addiction science.

In general, the concept of addiction studies can be used as a framework to describe the emerging education programs that focus on the interactions between science, clinical practice, and social policy and across a range of addiction topics (e.g., opiate addiction, nicotine dependence, gambling behavior, alcoholism). Figure 2.7 shows the cumulative growth in university-based degree programs in addiction studies. Some of these programs offer undergraduate- or graduate-level degrees, and they are often interdisciplinary, involving training in genetics, neuroscience, psychology, epidemiology, and public health.

Other programs, not included in the figure, offer postbaccalaureate, postdoctoral, or even single-workshop-based training options geared toward a variety of individuals interested in improving their clinical skills, research methods, and professional qualifications for positions in research, clinical services, prevention, and policy. The aim of addiction studies programs is not to replace other professions but to work with them to promote the integration of research findings, prevention activities, and clinical approaches. Table 2.3 describes some of the training programs in addiction studies.

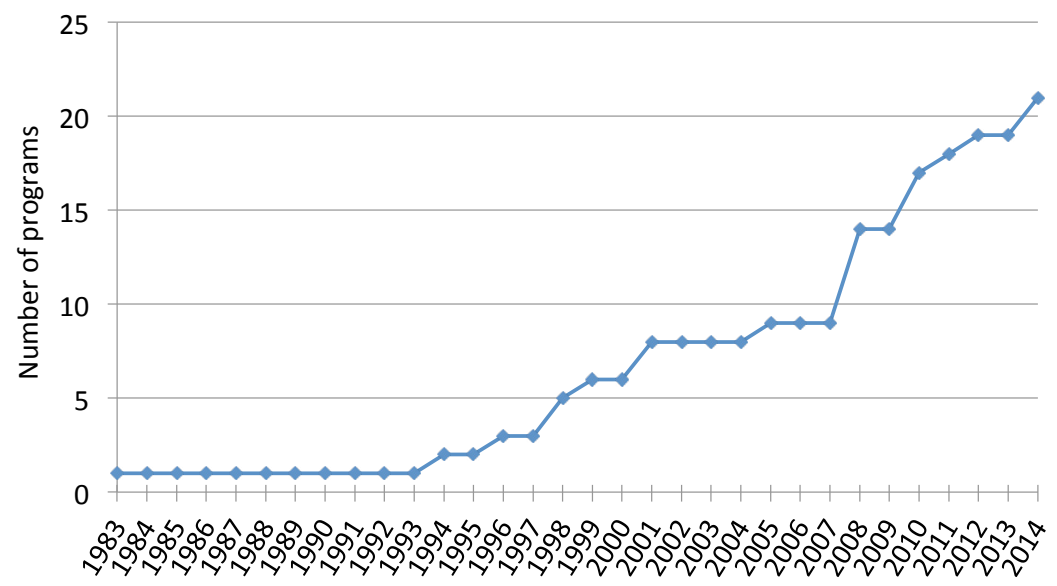

Fig. 2.7: Cumulative growth in degree programs in addiction studies. 


\begin{tabular}{|c|c|c|c|}
\hline University & Country & Degree & Program \\
\hline $\begin{array}{l}\text { Middlesex University, } \\
\text { Aarhus University and } \\
\text { University del Piemonte } \\
\text { Orientale "A Avogadro" }\end{array}$ & $\begin{array}{l}\text { England, } \\
\text { Denmark and } \\
\text { Italy }\end{array}$ & Master's degree & $\begin{array}{l}\text { European Masters } \\
\text { in Drug and } \\
\text { Alcohol Studies }\end{array}$ \\
\hline $\begin{array}{l}\text { National Addiction } \\
\text { Centre at the Institute } \\
\text { of Psychiatry, Maudsley } \\
\text { Hospital, King's College } \\
\text { London }\end{array}$ & England & $\begin{array}{l}\text { Master of science } \\
\text { degree }\end{array}$ & $\begin{array}{l}\text { Clinical and Public } \\
\text { Health Aspects of } \\
\text { Addiction }\end{array}$ \\
\hline $\begin{array}{l}\text { King's College } \\
\text { London, Virginia } \\
\text { Commonwealth } \\
\text { University and } \\
\text { University of Adelaide }\end{array}$ & $\begin{array}{l}\text { England, } \\
\text { United States } \\
\text { and Australia }\end{array}$ & $\begin{array}{l}\text { Joint master's- } \\
\text { level degree }\end{array}$ & $\begin{array}{l}\text { International } \\
\text { Programme in } \\
\text { Addiction Studies }\end{array}$ \\
\hline $\begin{array}{l}\text { Department of } \\
\text { Addictology, First } \\
\text { Faculty of Medicine, } \\
\text { Charles University }\end{array}$ & Czech Republic & $\begin{array}{l}\text { Bachelor's, } \\
\text { master's, and } \\
\text { doctoral degrees }\end{array}$ & $\begin{array}{l}\text { Academic Study } \\
\text { Programs in } \\
\text { "Addictology" } \\
\text { (Addiction Science }\end{array}$ \\
\hline $\begin{array}{l}\text { University of Auckland, } \\
\text { School of Populations } \\
\text { Sciences }\end{array}$ & New Zealand & $\begin{array}{l}\text { Postbaccalaureate } \\
\text { certificate, } \\
\text { postbaccalaureate } \\
\text { diploma, full } \\
\text { master's degree } \\
\end{array}$ & $\begin{array}{l}\text { Postbaccalaureate } \\
\text { specialization in } \\
\text { addiction science: } \\
\text { Alcohol and Other } \\
\text { Drugs Program }\end{array}$ \\
\hline $\begin{array}{l}\text { Center for Addiction } \\
\text { Science Specialties, } \\
\text { Sahmyook University }\end{array}$ & South Korea & $\begin{array}{l}\text { Connective } \\
\text { major for } \\
\text { bachelor degree } \\
\text { in Substance } \\
\text { Addiction and } \\
\text { Behavioral } \\
\text { Addiction } \\
\text { Prevention } \\
\end{array}$ & $\begin{array}{l}\text { Departments of } \\
\text { Nursing, Health } \\
\text { Management, } \\
\text { Counselling and } \\
\text { Physical Therapy }\end{array}$ \\
\hline $\begin{array}{l}\text { University of Dresden } \\
\text { (TUD) and Dresden } \\
\text { International University } \\
\text { (DIU) }\end{array}$ & $\begin{array}{l}\text { Germany, open } \\
\text { for } \mathrm{PhD} / \mathrm{MD} \\
\text { students from } \\
\text { Europe }\end{array}$ & $\begin{array}{l}\text { Certificate as } \\
\text { basis for the } \mathrm{MD} / \\
\mathrm{PhD} \text { degree at the } \\
\text { home university }\end{array}$ & $\begin{array}{l}\text { European } \\
\text { Graduate School } \\
\text { in Addiction } \\
\text { Research (ESADD) }\end{array}$ \\
\hline
\end{tabular}

Table 2.3: Examples of specialized addiction-studies programs.

An Internet search conducted by Charles University (Pavlovska et al., 2015) identified 79 university study programs at 24 different universities. The programs were distributed across all education levels, that is, bachelor's, master's, and doctorate, with 35 programs located in Europe, 34 in the United States and Canada, 7 in Australia and New Zealand, and 3 in Asia. 
The ultimate goal of this new academic area is to advance research-based knowledge, practice, and policies to further improve prevention and treatment of disorders and problems related to substance use. Despite the growth of programs for the training of addiction psychiatrists, narcologists, psychologists, social workers, psychiatric nurses, and addiction counselors, there has been little attention to the development of specialized training programs for addiction scientists. The value of having specially trained addiction scientists is to maintain, if not expand the global infrastructure for social, behavioral, biological, epidemiological and health services research.

The size of the addiction science workforce needed in a country will depend on the extent of addiction-related problems, the delegation of professional responsibilities, and the funding provided by governments to manage the problems of addiction. Globally, there is now a network of perhaps 10,000 people worldwide who identify addiction science as part of their career identity (Babor, 2012). Membership in the 10 professional societies listed in Table 2.2, which includes both basic and clinical scientists, is comparable to this number. Without more systematic attention to workforce monitoring, it is impossible to say whether the current number of addiction scientists is sufficient to meet the needs and the demands for scientific information about addiction.

\section{Funding Sources and Patronage}

How society allocates its resources to support the infrastructure of addiction science is not only testimony to its values, but it also is an indication of current priorities in relation to the management of society's addiction-related problems. As in other areas of science, the addiction field relies on patronage. In some cases, the support and sponsorship comes from private sources, such as when a philanthropist creates an endowment for a research center or an academic chair. More often, however, the patronage comes from public sources. During the past 50 years, a variety of funding mechanisms across the globe have provided support for addiction research and research infrastructure, which in turn has made possible much of the growth in professional careers (Babor, 2012). National research institutes, for example, have been created in many high- and middle-income countries to plan, support, and conduct scientific research on addiction (Babor, 1993b). Examples of such organizations include the Norwegian National Institute for Alcohol and Drug Research, the Indian National Drug and Alcohol Institute, the National Institute of Public Policy for Alcohol and Other Drugs (INPAD) in Brazil, and the National Research Centre on Addictions (Russian Federation). Many of these organizations have been established to support the development of scientific expertise with a clinical and sometimes a public health orientation, via the direct funding of research scientists, research training, public education, and the coordination of international activities. 
Another source of support for addiction research comes from the private sector, especially pharmaceutical companies. There has also been an increase in funding opportunities from the alcohol and gambling industries, both through direct support for research projects and programs and indirect support from organizations funded by these industries. As described in Chapter 16, there are some important ethical considerations involved in the acceptance of industry funding, not the least of which is financial conflict of interest.

Another issue is the role of funding agencies in the determination of the research agenda. Increasingly, the dollars dictate the science. Alcohol industry funding has been questioned because the agenda is often set by commercial objectives rather than by public health priorities. But even in the public sector, governments can shape the research agenda toward topics that may not address the most effective solutions for addiction problems.

Midanik (2006), for example, identified a bias in U.S. research-funding agencies' priorities toward biomedical (vs. psychosocial) approaches to alcohol-related problems. This has led to the majority of U.S. publications on drugs and alcohol being devoted to basic science and clinical interventions, which conflicts with the interests of policymakers on research related to supply control and demand reduction. In the European Union as well, there is a relative disconnect between research published on illicit drugs and the priorities advanced by policymakers who are responsible for funding research and using its results to lessen the

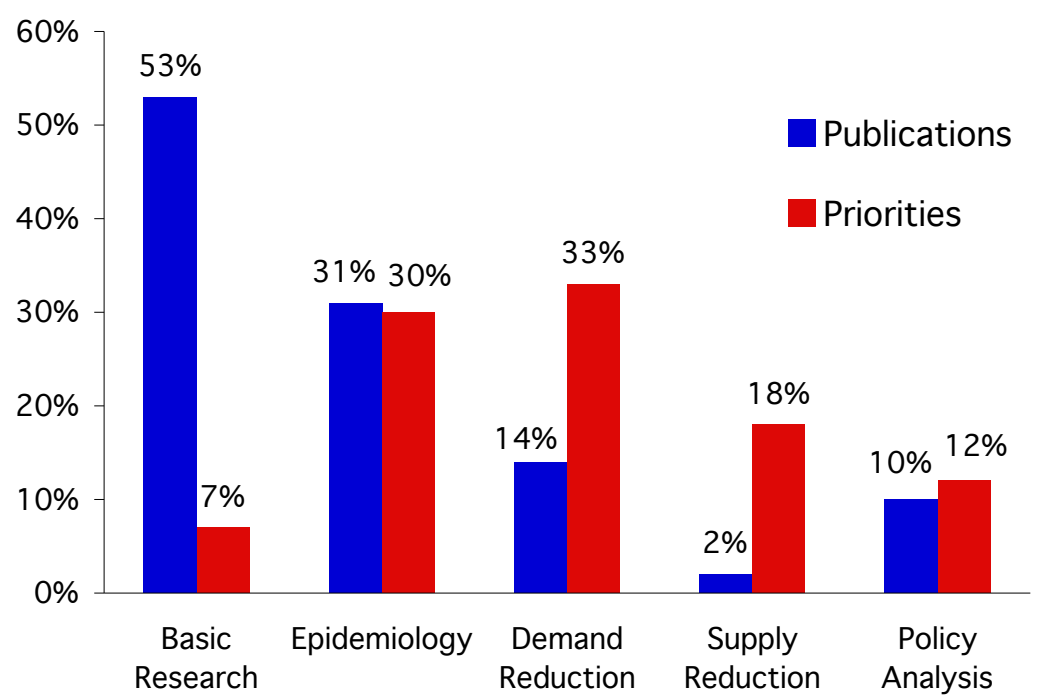

Fig. 2.8: Percentage distributions of research publications $(\mathrm{N}=3,028)$ and research priority ratings $(\mathrm{N}=57)$ across five research areas, based on data from European Union Member states $(\mathrm{N}=27)$. (Source: Bühringer et al., 2009). 
suffering of those who experience addiction-related problems (Bühringer et al., 2009). This disconnect between research and policy is reflected in the data presented in Figure 2.8, which contrasts the distribution of research publications in Europe with research priority ratings obtained from 57 policymakers from 27 European Union Members States. The figure shows an inverse relationship between the types of scientific evidence being published and the priorities of policymakers who fund the research behind the publications.

\section{Addiction Science as a Career Option}

As described in the infrastructure areas reviewed in this chapter, the field is built around institutions that help to define its roles and responsibilities. Professional societies, research centers, national institutes, addiction journals, specialized libraries, and specialized treatment programs constitute the major ingredients of the addiction field's infrastructure, but, as previously suggested (Edwards \& Babor, 2012), addiction careers constitute its building blocks and its human capital.

Today, the field of addiction science is populated by a variety of creative people: basic scientists in pursuit of knowledge for its own sake, clinical investigators searching for new or better treatments, and applied researchers trying to solve difficult social problems (Edwards \& Babor, 2012). How do people select a career in an emerging field that for most of its existence had no name or identity? As suggested by personal accounts derived from a long series of interviews published in the journal Addiction (Edwards \& Babor, 2012), the answer is as varied as the field itself. Personal experience with substance misuse, the influence of a mentor, the need to make a living, and the love of science are all mentioned. Some researchers and addiction professionals developed their interest in the field from personal, even tragic, experience. Others describe serendipity or "opportunity knocking."

With an identity defined by the work of a diverse group of career scientists and the prominence of mentors from a wide variety of disciplines, the career of an addiction scientist is no longer a risk or a mystery. Addiction science as such can now be perceived as an independent, professional career (Babor, 2012; Edwards, 2002).

\section{Conclusion}

In the past 50 years, there has been dramatic growth in the demand for and production of addiction science, both globally and in specific countries. Addiction science has evolved to become part of a specialized academic field, with its own training programs, professional organizations, research centers, funding mechanisms, and communication channels. It is devoted both to the pursuit of basic knowledge about addiction and the application of that knowledge to treatment and prevention activities. 
By integrating itself with the postwar biomedical establishment (particularly psychiatry), the addiction field experienced phenomenal growth. As suggested by the information presented in this chapter and elsewhere, that growth has been characterized by a number of "megatrends" (Babor, 1993b, 2000), as depicted in Figure 2.9. These trends include the following: (a) the emergence of public and private financing mechanisms to support treatment, prevention, and research programs; (b) development of an institutional base consisting of research centers, specialized clinical facilities, and related organizational structures; (c) the growth of professional societies to give the field a sense of identity and purpose; and (d) the rapid expansion of scientific communication outlets and publication opportunities to facilitate information exchange and dissemination. The final ingredient of the addiction field depicted in the figure is the result of all this effort-that is, basic and applied knowledge about addiction.

Although opinions will differ as to what constitutes the collective "products" of professional careers in academia and the health sector, from a societal perspective, the tangible products of the addiction field can be measured in terms of scientific knowledge, evidence-based clinical and prevention services, and policy interventions designed to address the consequences of psychoactive substance use. Ultimately, the cumulative and collective impact of these efforts should be the reduction of substance-related harm, suffering, and mortality.

The growth of addiction science has fostered increasing communication and collaboration on an international level. Part of this has been the result of the explosion of communications technology and the ease of international travel,

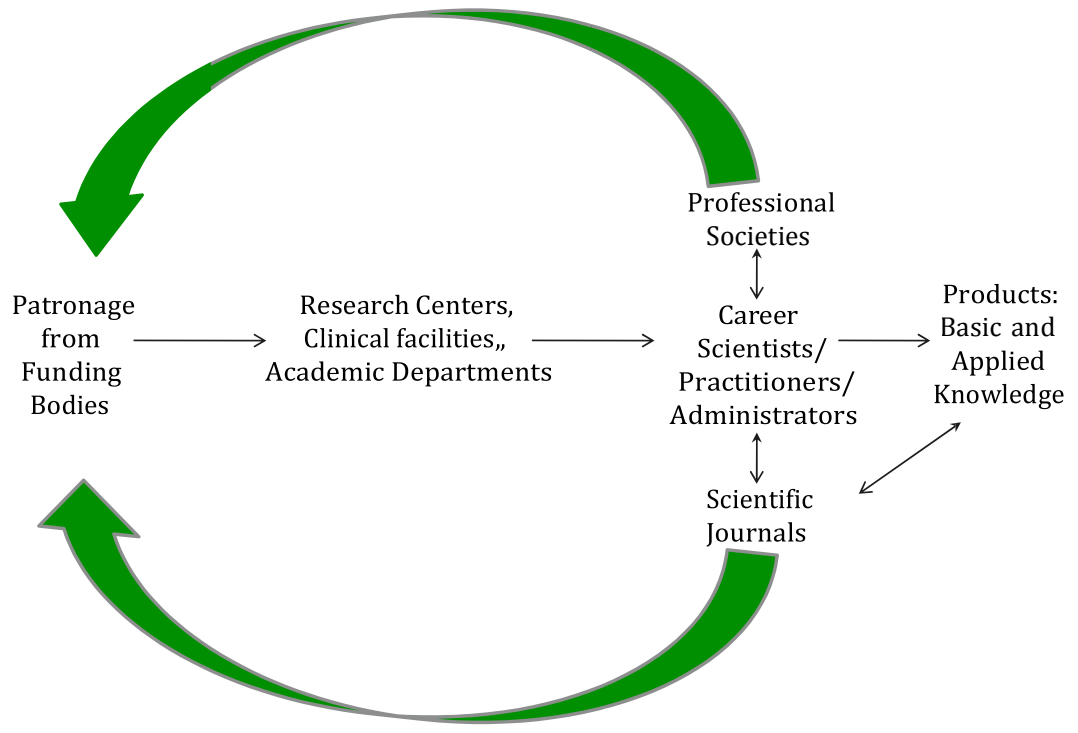

Fig. 2.9: "Megatrends" in addiction science. 
but it may also be the result of the globalization of alcohol and other drug distribution networks, which are bringing addictive substances to locations and populations that were previously unexposed. Examples include the marketing by transnational alcohol producers of new alcohol products to women and young adults and the growth of illicit drug use in the major population areas of Africa, Latin America, and Asia.

Perhaps most importantly, what impact does the modern addiction research infrastructure have on the health of the populations it is intended to serve? Countries invest in research on alcohol and other drugs for a reason. Typically, the purpose is to reduce human suffering caused by psychoactive substance use and to prevent further problems.

In most low- and middle-income countries, however, in which addiction presents the same harms as in more developed countries, addiction-research infrastructure is weak or absent. That a journal series on addiction societies and addiction research centers (Edwards \& Babor, 2008) could locate in the developing world only a few societies, centers, and journals devoted to the addictions suggests the need to support addiction science in less-resourced countries that have substantial addiction problems. Established groups could aid the development of such societies in large parts of the world that do not at present have this kind of resource. Any such initiatives would need to be culturally sensitive. Even in countries in which resources might not easily allow development of specialist treatment services, specialist research centers, or the publication of national journals, international collaboration combined with voluntary action catalyzed by local associations may constitute entirely feasible kinds of initiatives capable of considerable impact.

If research were the main vehicle for the development of a cure for addictionrelated problems, however, by now there should have been breakthroughs in translating research findings into effective prevention policy. As previously mentioned, there is a gap between the bulk of scientific research currently conducted and the interests of policymakers who set the agenda for prevention and treatment funds. Despite the field's apparent growth in many areas, the question of whether the modern infrastructure (surveillance, treatment, prevention, research) has a population-level impact remains unanswered. Until policymakers and addiction experts achieve a greater sense of mission and purpose, nation states will continue to struggle with the question of how best to configure a rational response to the problems of substance abuse.

Please visit the website of the International Society of Addiction Journal Editors (ISAJE) at www.isaje.net to access supplementary materials related to this chapter. Materials include additional reading, exercises, examples, PowerPoint presentations, videos, and e-learning lessons. 


\section{References}

Agrawal, A., \& Bierut, L. J. (2012). Identifying genetic variation for alcohol dependence. Alcohol Research and Health, 34(3), 274-281.

Anton, R. F., O’Malley, S. S., Ciraulo, D. A., Cisler, R. A., Couper, D., Donovan, D. M., . . . , Zweben, A. (2006). Combined pharmacotherapies and behavioral interventions for alcohol dependence: The COMBINE study: A randomized controlled trial. JAMA, 295, 2003-2017. DOI: https://doi.org/10.1001/jama.295.17.2003

Babor, T. F. (2000). Past as prologue: The future of addiction studies [Editorial]. Addiction, 95, 7-10. DOI: https://doi.org/10.1046/j.1360-0443.2000.95172.x

Babor, T. F. (2012). Addictionology as biography: One hundred ways to have a successful career in addiction science. Addiction, 107, 464-466. DOI: https://doi.org/10.1111/j.1360-0443.2012.03788.x

Babor, T. F., \& Del Boca, F. K. (Eds.). (2003). Treatment Matching in Alcoholism. Cambridge University Press: Cambridge, UK.

Babor, T. F., Morisano, D., Stenius, K., Winstanley, E. L., \& O’Reilly, J. (2008). How to choose a journal: Scientific and practical considerations. In T. F. Babor, K. Stenius, S. Savva, \& J. O’Reilly (Eds.), Publishing addiction science: A guide for the perplexed (2nd ed., pp. 15-32). Brentwood, UK: Multi-Science Publishing.

Babor, T. F., Stenius, K., \& Romelsjö, A. (2008). Alcohol and drug treatment systems in public health perspective: Mediators and moderators of population effects. International Journal of Methods in Psychiatric Research, 17(Supplement 1), S50-S59. DOI: https://doi.org/10.1002/mpr.249

Beall, J. (2012). Predatory publishers are corrupting open access. Nature, 489, 179. DOI: https://doi.org/10.1038/489179a

Billings, J. S., Eliot, C. W., Farnam, H. W., Greene, J. L., \& Peabody, F. G. (1905). The liquor problem: A summary of investigations conducted by the committee of fifty, 1893-1903. Boston, MA: Houghton Mifflin.

Bühringer, G., \& Watzl, H. (2003). On the history and new layout of the journal SUCHT: Old wine in new bottles? [Editorial] SUCHT, 49, 12-15. DOI: https://doi.org/10.1024/suc.2003.49.1.4

Bühringer, G., Farrell, M., Kraus, L., Marsden, J., Pfeiffer-Gerschel, T., Piontek, D., \& Stillwell, G. (2009). Comparative analysis of research into illicit drugs in the European Union. Executive summary. Brussels, Belgium: European Commission.

Choi, B. C., \& Pak, A. W. (2006). Multidisciplinarity, interdisciplinarity and transdisciplinarity in health research, services, education and policy: 1 . Definitions, objectives, and evidence of effectiveness. Clinical \& Investigative Medicine, 29, 351-364.

Dias da Silva, J. C., Ramos, S. d. P., Luz, E. L. Jr., de Oliveira, E. M., Requião, D. H., \& Campana, A. A. M. (2002). The Brazilian Association for the Study of Alcohol and Other Drugs. Addiction, 97, 9-13. DOI: https://doi. org/10.1046/j.1360-0443.2002.00013.x 
Edwards, G. (Ed.). (2002). Addiction: Evolution of a specialist field. Oxford, England: Blackwell.

Edwards, G., \& Babor, T. F. (2001). The International Society of Addiction Journal Editors (ISAJE) has become established. Addiction, 96, 541-542. DOI: https://doi.org/10.1046/j.1360-0443.2001.9645411.x

Edwards, G. E., \& Babor, T. F. (2008). Closing remarks: Addiction societies as valuable assets. Addiction, 103, 9-12. DOI: https://doi.org/10.1111/j.13600443.2007.02095.x

Edwards, G., \& Babor, T. F. (Eds.). (2012). Addiction and the making of professional careers. Piscataway, NJ: Transaction Publishers.

Israel, Y., \& Lieber, C. S. (2002). The Research Society on Alcoholism. Addiction, 97, 483-486. DOI: https://doi.org/10.1046/j.1360-0443.2002.00012.x

Keller, M. (Ed.). (1966). International bibliography of studies on alcohol. New Brunswick, NJ: Rutgers Center of Alcohol Studies.

Krimsky, S. (2003). Science in the private interest: Has the lure of profits corrupted biomedical research? Lanham, MD: Rowman \& Littlefield.

Lafollette, M. C. (1992). Stealing into print. Fraud, plagiarism, and misconduct in scientific publishing. Berkeley, CA: University of California Press.

Mann, K., \& Batra, A. (2008). The German Society for Addiction Research and Addiction Treatment. Addiction, 103, 6-8. DOI: https://doi.org/10.1111/ j.1360-0443.2007.02028.x

Mann, K. (2010). Addiction Research Centres and the Nurturing of Creativity: Department of Addictive Behaviour and Addiction Medicine, Central Institute of Mental Health, Mannheim, University of Heidelberg. Addiction, 105, 2057-2061. DOI: https://doi.org/10.1111/j.1360-0443.2010.02974.x

Maruyama, K., \& Higuchi, S. (2004). The Japanese society of alcohol-related problems. Addiction, 99, 419-424. DOI: https://doi.org/10.1111/j.13600443.2004.00712.x

McTernan, J. (2016, March 29). Don't mourn the loss of libraries - the internet has made them obsolete. The Telegraph. Retrieved from http://www. telegraph.co.uk/news/12206475/Dont-mourn-the-loss-of-libraries-theinternet-has-made-them-obsolete.html.

Midanik, L. T. (2006). Biomedicalization of alcohol studies: Ideological shifts and institutional challenges. New Brunswick, NJ: Aldine Transaction.

Mitchell, A. (1991). SALIS directory 1991: An international directory of alcohol, tobacco, and other drug libraries, clearinghouses, resource and information centers: Includes state and specialty regional alcohol and drug awareness resource (RADAR) centers. San Francisco, CA: Alcohol Research Group, Medical Research Institute of San Francisco.

Mitchell, A. L., Lacroix, S., Weiner, B. S., Imholtz, C., \& Goodair, C. (2012). Collective amnesia: Reversing the global epidemic of addiction library closures. Addiction, 107, 1367-1368. DOI: https://doi.org/10.1111/j.1360-0443.2012.03813.x

National Institute on Alcohol Abuse and Alcoholism. (1985). Resource directory of national alcohol-related associations, agencies and organizations. Rockville, MD: Author. 
Nizzoli, U., \& Foschini, V. (2002). ERIT-Italia, the Italian federation for professionals working in the field of drug abuse. Addiction, 97, 1365-1367. DOI: https://doi.org/10.1046/j.1360-0443.2002.00137.x

Pavlovská, A., Miovský, M., Gabrhelík, R., \& Babor, T. (2015). European University-based study programmes in the addictions field. Unpublished manuscript, Department of Addictology, 1st Faculty of Medicine, Charles University, Prague, Czech Republic.

Sournia, J. C. (1996). A history of alcoholism. Basil, Blackwell.

Stenius, K. (2012). ICARA: A global forum for research associations. Nordic Studies on Alcohol and Drugs, 29, 439-440. DOI: https://doi.org/10.2478/ v10199-012-0038-3

Taylor, P., \& Keeter, S. (2010). Millennials: A portrait of generation next. Pew Research Center Report. Retrieved from http://www.pewsocialtrends.org/ files/2010/10/millennials-confident-connected-open-to-change.pdf.

Tober, G. (2004). The Society for the Study of Addiction (SSA). Addiction, 99, 677-685. DOI: https://doi.org/10.1111/j.1360-0443.2004.00729.x

Wells, E. A., Saxon, A. J., Calsyn, D. A., Jackson, T. R., \& Donovan, D. M. (2010). Study results from the Clinical Trials Network's first ten years: Where do they lead? Journal of Substance Abuse Treatment, 38(Supplement 1), S14-S30. DOI: https://doi.org/10.1016/j.jsat.2009.12.009

World Bank. (2013). Retrieved from http://data.worldbank.org/indicator/ SP.POP.TOTL.

\section{Appendix A. Search Terms Used in SCOPUS Search of Addiction Publications (2000-2014)}

\begin{tabular}{|c|c|c|}
\hline \multirow[t]{2}{*}{ Search Terms } & \multicolumn{2}{|c|}{ \# of results } \\
\hline & 2010-2014 & 2000-2014 \\
\hline $\begin{array}{l}\text { Alcohol ("alcohol drinking" OR "alcohol-related problems" } \\
\text { OR "alcohol intoxication" OR "alcohol abuse" OR "alcohol- } \\
\text { induced disorder\$" OR "alcohol use" OR "alcohol-related } \\
\text { harm\$" OR "alcoholism" OR "alcohol use disorder\$") }\end{array}$ & 28,667 & 74,921 \\
\hline $\begin{array}{l}\text { Tobacco ("tobacco smoking" OR "smoking cessation" OR } \\
\text { "cigarette smoking" OR "tobacco use disorder\$") }\end{array}$ & 21,528 & 64,346 \\
\hline $\begin{array}{l}\text { Drugs ("street drug\$" OR "illicit drug\$" OR "illegal drug\$" } \\
\text { OR "drug dependence" OR "drug use disorder\$” OR "drug } \\
\text { abuse" OR "marijuana" OR "heroin" OR "hallucinogens" } \\
\text { OR "cocaine" OR "cannabis") }\end{array}$ & 31,425 & 86,402 \\
\hline Gambling ("gambling" OR "pathological gambling") & 3,192 & 6,115 \\
\hline
\end{tabular}

